\title{
A NARRATIVE INQUIRY OF STUDENT TEACHERS MULTIMODAL PRACTICE EXPERIENCES IN THE INDONESIAN ESP CLASSROOM CONTEXT
}

\author{
Elih Sutisna Yanto*1, Hikmah Pravitasari" ${ }^{* 2}$ \\ elih.sutisna@fkip.unsika.ac.id ${ }^{* 1}$, hikmah@latansamashiro.ac.id $^{* 2}$ \\ English Education Department, Faculty of Teaching and Education ${ }^{* 1}$, \\ English Education Study Program ${ }^{* 2}$ \\ Universitas Singaperbangsa Karawang, Karawang West Java, Indonesia* ${ }^{* 1}$, STKIP La \\ Tansa Mashiro, Rangkasbitung Lebak Banten, Indonesia ${ }^{* 2}$
}

\begin{abstract}
Drawing on narrative inquiry aiming to understand the experience of student teachers learned Statistics for TESOL research texts through different tasks of learning such as: lexico-grammaring responding interpreting analyzing, searching or navigating video viewing intertextualizing resemitiozing and listing the key concepts by using learning logs learning context texts through different modes of meaning. This paper reports on the use of narrative frames as a mean of investigating the intersemiotic practice experiences of two student teachers majoring in English education program at one state universities in Karawang, West Java, Indonesia. Students in depth interview data revealed that multimodal practice has the potential to promote the role of student teachers as designers and navigators in reading English disciplinary texts. In addition, through completing learning logs: grammar log, reading log and vocabulary log, student teachers were asked to record different tasks that they did. These activities encouraged the student teachers to become autonomous language learners. Moreover, multimodality reading tasks can scaffold students in comprehending academic language and in increasing students' academic vocabulary development as well. These findings have implications for policy makers and teacher educators in English education program context.
\end{abstract}

Keywords: academic language, autonomous language learning, disciplinary text, multimodal reading, narrative inquiry

DOI: https://doi.org/10.31943/wej.v4i1.81

\section{INTRODUCTION}

The global use of the internet might have influenced higher education institutions in Indonesia to follow the current trend of the technological usage. It also has an impact to the learning design in English classroom. Teaching English in digital era might be a challenge to the teachers to create an appropriate learning design and choose the applicable method to make an interactive classroom. Diaries and logs have been used in a number of different learning contexts. In completing learning $\operatorname{logs}$ for Statistics for TESOL research, student teachers are 
asked to record the different activities that they did. This article aims to provide empirical information on the experience of the two student teachers in using multimodal texts and learning logs practice experience in English Specific Purposes (ESP) classroom using narrative inquiry method in English education program context. Walsh contends, (2010,p.213) "Multimodal literacy refers to meaning-making that occurs through the reading, viewing, and understanding, responding to and producing and interacting with multimedia and digital texts It may include oral and gestural modes of talking, listening and dramatizing as well as writing, designing and producing such texts. The processing of modes, such as image, words, sound and movement within texts can occur simultaneously and is often cohesive and synchronous (Kress \& van Leeuwen, 2001; Walsh, 2010). Meanwhile, narrative inquiry in this research will be used as a method to inform ESP classroom activities using various kinds of intersemiotic activities. Narrative inquiry brings storytelling and research together either by using stories as research data or by using storytelling as a tool for data analysis or presentation of findings (Barkhuizen, 2014, p.3). Following Polkinghorne (1995) in Barkhuizen, 2014, p.3, "analysis of narratives" refers to research in which stories are used as data, while "narrative analysis" refers to research in which storytelling is used as a means of analyzing data and presenting findings. Narrative inquiry in language pedagogy aims to understand the experiences of teachers in which they teach and students in which they learn in the particular contexts (Barkhuizen, 2014). Narrative inquiry is an effective means to spell out as about who people are, how they view themselves and how they act (Czarniawska-Joerges, 2004).

This study focuses on providing empirical impormation of the two student teachers intersemiotic practice experiences in learning content and language by using different kind of reading activities or tasks. Intersemiotic practice refers to the principle of resemiotisation, which is concerned with "how meaning shifts from context to context, from practice to practice, or from one stage of a practice to the next" (Iedema 2003, p. 41). Iedema (2001, p. 23-24) in Moore (2019) describes the movement of 'meaning making' from the 'temporal' (for example, speech, embodied actions) to the 'durable' (which, in the case of the building project he discusses, are written reports, designs, plans and constructions). Freebody and Luke (1990) in Serafini (2012) proffered an expanded conceptualization of the resources readers utilize and the roles readers adopt during the act of reading. The four resources model and its associated four roles of the reader expanded the definition of reading from a simple model of decoding printed texts (Gough, 1972 in Serafini, 2012) to a model of constructing meaning and analyzing texts in sociocultural contexts (Gee, 1996 in Serafini, 2012). The goal was to shift the focus from trying to find the right method for teaching students to read to determining whether the range of resources available and the strategies emphasized in a reading program were indeed covering and integrating the broad repertoire of practices required in today's digital era. Based on the classroom observation did by Widodo, (2008), there are eight main selected behaviors in teaching extensive reading as consecutively presented as follows: (1) teacher lesson opening; (2) student awareness of self-learning determination; (3) teacher scaffolding; (4) student awareness of learning pace; (5) student empowerment through varied reading skills; (6) dynamic interactions between 
students and a teacher; (7) the nature of questions arising from classroom interactions; and (8) roles of observers. When reading multi-modal texts, the skill of decoding written text needs to be accompanied by an understanding of the structures and codes associated with design, images and other visual elements (Kress \& van Leeuwen, 2001). In addition to decoding written language, readers must learn to navigate the design of written text, including the left to right orientation of English language texts, and understand the role and structures of charts, graphs, diagrams and other visual images encountered in picture books, informational texts, graphic novels, websites, advertisements and other multimodal texts (Serafini, 2012).

\section{LITERATURE REVIEW}

Recent previous studies on multimodal literacy (Tungka, 2018) revealed the implementation of guided literacy instruction in reading multimodal English medium texts. This research reported a phenomenological study investigating the implementation of guided literacy instruction, geared to L2 students in reading multiple texts as the fabric of today's literacy practice. Guided literacy instruction in this study aimed to promote the role of a student reader as a designer, navigator, interrogator, and interpreter in reading multimodal English medium texts. Meanwhile, Serafini's (2012), article continues the reconceptualization of the four resources model to four resources or social practices for reading-viewing multi-modal texts by Freebody and Luke (1990). Another study explores the tension between self-knowledge and self-expression, and how it manifests in the processes of storytelling that unfold in digital storytelling (Rose \& Granger, 2012). Binder \& Kotsopoulos (2011) examined how children develop multimodal narratives through the construction of quilt squares that used personal artifacts, or "things of importance," to represent who they were and what was important in their world. The use of "I Am" poetry (Ada \& Campoy, 2004 in Binder \& Kotsopoulos 2011) augmented the visual narratives or story quilts, empowering and validating children's voice in this artistic multimodal experience. The study focused on the processes and growth that a group of diverse kindergarten children underwent over 9 weeks and explored the multimodal experiences through the arts and how they transformed young children's literacy understanding of identity texts. This current study explores the multimodal practice experiences of student teachers majoring in English education program of ESP classroom using narrative inquiry method. Moreover, the research will describe multimodal reading activities using intersemiotic practice in producing and interacting with multimedia and digital texts.

\section{RESEARCH METHODOLOGY Research Method}

The process of narrative inquiry of student teachers intersemiotic practice practice experience used individuals narratives. The authors propose research question in this study was to which extent the intersemiotic practice is pedagogically workable in assisting students to become more autonomous and motivated not only to learn about language, but also to learn through language? A narrative inquiry design is used to explore one's lived experience (Clandinin \& 
Connely,2000; Clandinin \& Rosiek,2007). This research design allows the recent study to closely explore participants' practices in using multimodal texts through their lived experiences in learning content and language jointly.

\section{Participants}

Before the research began, the authors convened a meeting with twenty six student teachers who enrolled the Statistics for TESOL research course. We asked them to participate voluntarily in doing interview after the course accomplished. Two participants Alif and Nasya (one male and one female, pseudonyms) agreed to be recruited as interviewees in this research. The participants were multilingual. Table 1 presents the participants ${ }^{\text {ee }}$ demographic information. The participants, the third year student teachers who enrolled in the course of Statistics in language research, were sophomores majoring in English education program.

Tabel 1. Participants' demographic information

\begin{tabular}{|c|c|c|c|c|c|c|}
\hline $\begin{array}{c}\text { Participants } \\
\text { (Pseudonyms) }\end{array}$ & Gender & Age & $\begin{array}{c}\text { Linguistics } \\
\text { Background }\end{array}$ & $\begin{array}{c}\text { Educational } \\
\text { Background }\end{array}$ & $\begin{array}{c}\text { Length of } \\
\text { English } \\
\text { learning } \\
\text { Experience } \\
\text { (approximately) }\end{array}$ & $\begin{array}{c}\text { Socio- } \\
\text { economic } \\
\text { background }\end{array}$ \\
\hline Alif & Male & 19 & $\begin{array}{c}\text { Sundanese } \\
\text { Indonesian } \\
\text { Arabic }\end{array}$ & $\begin{array}{c}\text { Undergraduate } \\
\text { studies }\end{array}$ & 10 years & $\begin{array}{c}\text { Mediocre- } \\
\text { socio } \\
\text { economic } \\
\text { status }\end{array}$ \\
\hline Nasya & Female & 19 & $\begin{array}{c}\text { Javanese } \\
\text { Indonesian } \\
\text { Arabic }\end{array}$ & $\begin{array}{c}\text { Undergraduate } \\
\text { studies }\end{array}$ & 10 years & $\begin{array}{c}\text { Mediocre- } \\
\text { socio } \\
\text { economic } \\
\text { status }\end{array}$ \\
\hline
\end{tabular}

This study spanned over four months of data gathering. We convened five meetings after class with the student teacher participants to detail the research project ethically using discuss informed consent, and distribute consent forms. We also emphasized that their participation was fully voluntary; the participants had to be informed about their rights not to take part in the research if they did not wish to and that withdrawal would not have deliberately negative consequences for them (Beach \& Eriksson, 2010).

\section{Data collection and Analysis}

Data were collected through in-depth interviews using Bahasa Indonesia to ensure full understanding of the research purpose regarding the student teachers experience in practicing intersemiotic tasks with learning logs. The interview lasted two 40-50 minutes and were conducted in a relaxed and conversational way and at each session the participants shared their intersemiotic practice experiences, the "circulation of meaning between different sign systems; for example, the image includes reference to the text, and the text referring to the image." Aktulum (2017, p.34), in learning content (Statistics for TESOL research) and language in their local contexts. In addition, each of the participants was interviewed two times where they narrated their lived experiences in learning content and language in their ESP classroom context. They were asked to recount their initial encounters with content and language that covered their engagement in video 
viewing, learning logs and multimodal reading tasks. For instance, they were asked to describe to what extent they engage in meaning making activities (e.g., personalizing digital dictionaries and corpus, creating graphic organizers, and listing key concepts by using learning logs).

The interview data were transcribed and take noted to repeatedly through close, selective, and analytical listening (see Widodo, 2014) to comprehensively capture the message or meanings presented in the interview texts. For the data analysis in this study, the data were treated as a bottom-up, inductive and emergent process in order to find emerging themes by way of using several levels of coding while analyzing the data to find relevant events, experiences, and expressions to create the themes. This thematic analysis (Riessman, 2003) applied in this study emphasizes "what" is said more than "how" it is said, the "told" rather than the "telling." The analysis focuses on the content of the story rather than on the linguistic features of the utterances. In this experience-centered narrative study (Squire, 2014), participantse ${ }^{\text {se }}$ stories were examined across the stories. We went forward and backwards across time in varying degrees of specificities, which sometimes led to other-related topics (Riessman, 2003).

\section{FINDING AND DISCUSSION}

The findings will be presented under the two headings informed by the two participants about their engagement in video viewing and learning logs. For instance, they were asked to describe to what extent they engage in meaning making activities (e.g., personalizing digital dictionaries and corpus, creating and listing key concepts by using learning logs).

\section{Students' Experiences in Intersemiotic Practices Alif's experiences in Video Viewing}

Alif enjoyed watching the video of contents i.e., basic statistics out of the class. He used the videos for learning academic language or disciplinary vocabulary since they learned disciplinary vocabulary in authentic contexts where specific words were used in specific social situations. He told that video viewing contained authentic vocabulary. He engaged video viewing in learning academic language or specialized vocabulary.

The following is an example of students' experience on video viewing. In this excerpt, Alif ( interview, 12 December 2019)is talking about his experience on video viewing.

Navigating and viewing video for learning basic statistics were fun, interesting, and easy. The video provided quick access to the visual text I hunted for. For instance, when I was assigned to discover the topics about descriptive statistics i.e., organizing and graphing data, measures of central tendency and measures of variability. I tried to type key words, such as descriptive statistics. Then, the machine browser, Google-YouTube, informs me a variety of video lesson about descriptive statistics. Simply by clicking on key words, I could easily get the assigned video. Through Google as browser and detector, I became an autonomous learner.) To me, surfing video in navigating content i.e., statistics lessons through the YouTube gives me a lot of choices. This digital engine gave me unlimited access to variety video-based sample statistics lesson. I do enjoy surfing different the videos which are relevant to my need. In my opinion, navigating digital texts via video viewing related to my course, statistics for TESOL research was a useful activity. 
Scaffolded and facilitated by the machine browser, Google - YouTube, and his navigating skill, Alif's learning autonomy emerged. Alif's experience shows that he felt that the use of the Web was helpful; he navigated digital texts based on the content, statistics for TESOL research that he was learning. Alif contended that the role of Google as browsing machine enable him to find relevant texts assigned in the lesson units. He expressed that this tool provided easy and quick access to a huge of digital texts.

\section{Nasya's experience on Engaging with learning logs}

Nasya described her experience on listing key statistical concepts using learning logs in order she became autonomous learner. She told that learning log could help her be independent and active learners in comprehending statistical concept as stated in the following excerpts.

I encountered unknown words such as standard error, confidence interval, a frequency distribution and class interval. To solve this lexical difficulty, I used learning logs to help me to understand unknown words independently.. I felt fortunate that my lecturer introduced me learning log especially vocabulary and grammar logs. These logs functioned in keeping track of what lexico-grammatical resources I learned. With learning $\log$ I could be more actively and independently find the meanings of unfamiliar words in the statistics texts by reading them repeatedly without employing learning log, I might have only found the meanings of the words without trying to understand entirely and I might have quickly forgotten the meaning of the texts. Through learning logs I could find new academic words in statistic texts actively and enthusiastically.

Nasya expressed that learning log could facilitate her to understand unknown words actively and independently. She also stated that she was able to systematically record some academic words to comprehend the statistics texts. More importantly, by using these tools, she extremely motivated to learn new academic words and to comprehend the statistical texts by reading it repeatedly. Through learning logs, Nasya was enjoyable to learn content and language. It was effective and helpful in learning disciplinary vocabulary. She was also interesting that she could learn the words by finding the meanings using on line dictionary and corpus. Through learning logs, she could know the disciplinary vocabularies from statistic texts. For her, learning logs were effective reading strategy that helps her learn from a text. With these strategies she could interact and share her logs with the class. This student attitudes towards this activity are also articulated in previous studies by Absalom \& De Saint Léger (2011) and Litzler 2014).

This narrative inquiry study showed that Alif and Nasya expressed their experiences during they learned content of statistics for TESOL research texts. The stories of their experiences served as a narrative site through which their autonomous learners of undergraduate students at English language education program was shaped and reshaped in relation to their activities with intersemiotic practice.

When Alif and Nasya read the statistics for TESOL research texts digitally, they should also become an interpreter when reading multimodal texts. In this case, they act as individual who is able to construct meanings and respond to the various communicative modes in the text (Kress, 2005; Serafini, 2012a, 2012b; Youngs \& Serafini, 2011). What Alif and Nasya did how to activate his or her 
funds of knowledge or their prior knowledge when encountering the different statistics for TESOL research text related his or her experiences to the texts, and constructed understandings from multiple perspectives.

Drawing on interview data, Alif and Nasya engaged in meaning making activities (e.g., personalizing digital dictionaries and corpus and listing key concepts by using learning logs). They engaged with a variety of statistics for TESOL research texts as unit of analysis and they read and shared the result of the analysis with their classmates. They shared, negotiated, and discussed ideational, interpersonal and textual meanings of the texts. They explored linguistic aspects of the statistics they learned. Hence, comprehending how language works in text both digital and printed provided them with a critical way to understand content knowledge (e.g., statistics concepts and terms) and statistical practices.

\section{CONCLUSION}

The findings of this study show that the formation of autonomy learning of the two participants was influenced by their engagement with multimodal practice experiences or intersemiotic practices. The study has demonstrated through lived experiences of the participants how their independent learning was negotiated and transformed through different activities with multimodal literacy.

The pedagogical implications can be drawn. As Alif and Nasya's stories show, the participants were motivated not only to learn about language, but also to learn through language. In this case, the participants should be provided with authentic multimodal and relevant learning in terms of their needs and choices. Second, intersemiotic practices can scaffold comprehension and production of academic language, finally multimodal reading can support students in increasing their academic writing and academic vocabulary mastery. We acknowledge that a more complete pictures of the enactment of intersemiotic practice using learning logs both in ESP and general English classrooms could be provided in future studies. For example, an experimental study may be conducted to look at to what extent multimodal reading with learning logs impact on students achievement. A qualitative case study may also be undertaken to search in what ways different types of teacher scaffolding and peer assistant in disciplinary or content instruction in English as a Foreign Language or English as an Additional Language Contexts help student teachers become competent and engaged leaners. This future research agendas aim to document more empirical evidence regarding to the use of multimodal reading instruction in different educational contexts and in other TESOL contexts in particular.

\section{REFERENCES}

Absalom, Matthew \& De Saint Léger, Diane (2011): "Reflecting onreflection: Learner perceptions of diaries and blogs in tertiary language study", Arts \& Humanities in Higher Education, 10 (2), 189-211, doi: $10.1177 / 1474022210389141$.

Aktulum, K. (2017). What Is Intersemiotics? A Short Definition and Some examples. International Journal of Social Science and Humanity, 7(1), 33. 
Barkhuizen, G., \& Wette, R. (2008). Narrative frames for investigating the experiences of language teachers. System, 36(3), 372-387.

Barkhuizen, Gary, Phil Benson, \& Alice Chik. (2014). Narrative Inquiry in Language Teaching and Learning Research. New York: Routledge.

Binder, Marni \& Kotsopoulos, Sally. (2011). Multimodal Literacy Narratives: Weaving the Threads of Young Children's Identity Through the Arts. Journal of Research in Childhood Education, 4, 25, 339-363, doi: 10.1080/02568543.2011.606762.

Czarniawska-Joerges, B. (2004). Narratives in social science research. Thousand Oaks, CA: Sage.

Clandinin, D. J., \& Connelly, F. M. (2000). Narrative inquiry: Experience and story in qualitative research. San Francisco, CA: Jossey-Bass.

Clandinin, D. J., \& Rosiek, J. (2007). Mapping the landscape of narrative inquiry: Borderlands spaces and tensions. In D. J. Clandinin (Ed.), Handbook of narrative inquiry: Mapping a methodology (pp. 35-76). Thousand Oaks, CA: Sage.

IEDEMA, Rick (2003), "Multimodality, Resemiotisation: Extending the Analysis of Discourse as Multi-semiotic Practice", Visual Communication, pp. 29-57. DOI: $10.1177 / 1470357203002001751$.

Kress, Gunther \& Van Leeuwen, Theo. (2001). Multimodal Discourse: The Modes and Media of Contemporary Communication. New York: Oxford University Press.

Kress, G. (2005). Literacy in the new media age. New York: Routledge.

Moore, Emilee \& Jessica Bradley. (2019). Resemiotisation from Page to Stage: Translanguaging and the Trajectory of a Musilingual Youth's Poem. International Journal of Bilingual Education and Bilingualism, doi.org/10.1080/13670050.2019.1600470

Litzler, Mary Frances, (2014a): "Independent Study Logs: Guiding and Encouraging Students in the Process of Language Learning", Journal of Language Teaching and Research, 5 (5), 994-998, doi: 10.4304/j1tr.5.5.994-998

Riessman, C.K (2003). Narrative analysis. In M. S. Lewis-Beck, A. Bryman, \& T. Futing Liao (Eds.), The Sage encyclopedia of social science research methods (pp.1-8). London: Sage.

Rose, Chloë Brushwood \& Granger, Colette A. (2012). Unexpected Selfexpression and the Limits of Narrative Inquiry: Exploring Unconscious Dynamics in A Community-based Digital Storytelling Workshop. International Journal of Qualitative Studies in Education, 2, 26, 216-237, doi: 10.1080/09518398.2012.666286. 


\section{Elih Sutisna Yanto $^{* 1}$, Hikmah Pravitasari ${ }^{* 2}$ \\ A NARRATIVE INQUIRY OF STUDENT TEACHERS MULTIMODAL PRACTICE \\ EXPERIENCES IN THE INDONESIAN ESP CLASSROOM CONTEXT}

Serafini, F. (2012a). Expanding the four resources model: reading visual and multi-modal texts. Pedagogies: An International Journal, 7, 150-164. doi: 10.1080/1554480X.2012.656347

Serafini, F. (2012b). Reading multimodal texts in the 21 st century. Research in the Schools, 19(1), 26- 32. Retrieved from https://www.learntechlib.org/p/91510

Squire, C., Andrews, M., Davis, M., Esin, C., Harrison, B., Hyden, L. C., \& Hyden, M. (2014). What is narrative research? London: Bloomsbury Publishing.

Tungka, Novalita Fransisca. (2018). Guided Literacy Instruction: Helping Students Read Multimodal English-Medium Texts. Indonesian Journal of Applied Linguistics, 2, 8, 345-357, doi: 10.17509/ijal.v8i2.13281.

Walsh, Maureen. (2010). Multimodal Literacy: What does it mean for classroom practice? Australian Journal of Language and Literacy, 3, 33, 211-239.

Widodo, H. P. (2008). Extensive Reading in an ESL Class in the United States: Some Good Points. Reflections on English Language Teaching, Vol. 7, No. 1, pp. 71-76.

Widodo, H. P. (2014). Methodological considerations in interview data transcription. International Journal of Innovation in English Language Teaching and Research, 3 (1), 101-107.

Youngs, S., \& Serafini, F. (2011). Comprehension strategies for reading historical fiction picture books. The Reading Teacher, 65, 115-124. doi: 10.1002/TRTR.01014

\section{Bio statement}

Elih Sutisna Yanto earned his MA in English Education at Universitas Profesor DR. Hamka Jakarta in 2012. He is a full-time English teacher at Universitas Singaperbangsa Karawang in West Java, Indonesia. His professional interests include language teaching methodology, systemic functional linguistics (SFL) in language education and the use of corpus in teaching grammar. He has published on language teaching methodology issues in national journals. $\mathrm{He}$ has also participated in many national \& international ELT and Linguistics and Literatures conferences.

Hikmah Pravitasari received her Master of Education at Universitas Muhammadiyah Surakarta in 2017. She is a full-time English teacher at STKIP La Tansa Mashiro Rangkasbitung, Lebak Banten, Indonesia. Her professional concerns are instructional design material evaluation and development, digital literacy, and discourse analysis. She has also participated in several national \& international ELT and Linguistics and Literatures conferences. 